\title{
Evaluation of a tubular heat exchanger for preheating a cell suspension of Tsukamurella paurometabola
}

\section{Evaluación de un intercambiador de calor tubular para el precalentamiento de una suspensión celular de Tsukamurella paurometabola}

\author{
Pérez-Sánchez Amaury \\ Universidad de Camagüey, Cuba \\ Facultad de Ciencias Aplicadas a la Industria \\ Departamento de Química \\ E-mail: amauryps@nauta.cu \\ Paneque-Díaz Yunier \\ Centro de Ingeniería Genética y Biotecnología de Camagüey, Cuba \\ Departamento de Producción \\ E-mail: yunier.paneque@cigb.edu.cu \\ Ramos-López Lisandro \\ Universidad de Camagüey, Cuba \\ Facultad de Ciencias Aplicadas a la Industria \\ Departamento de Alimentos \\ E-mail: lisandro.ramos@reduc.edu.cu
}

\author{
Zamora-Sánchez Jesús \\ Centro de Ingeniería Genética y Biotecnología de Camagüey, Cuba \\ E-mail: jesus.zamora@cigb.edu.cu
}

Crespo-Zafra Lourdes

Universidad de Camagüey, Cuba

Facultad de Ciencias Aplicadas a la Industria

Departamento de Ingeniería Química

E-mail: lourdes.crespo@reduc.edu.cu

\begin{abstract}
Today, the development and implementation of more efficient and profitable thermal processes constitute a topic with high priority in a great amount of industries and chemical plants. At the present work the experimental evaluation of a tubular heat exchanger is carried out in order to preheat a liquid cell suspension (bio-formulate) of Tsukamurella paurometabola bacteria strain C-924, as an alternative to substitute the current batch preheating method. Cell viability studies, as well as chemicals and electricity consumption studies, were carried out for both preheating methods considered (batch and continuous), while the results obtained were mutually compared. Batch preheating mode reduces the cell viability of the bio-formulate in $75 \%$ during the first 6 hours of preheating, while the application of the continuous preheating method using the tubular heat exchanger don't reduces the viability of the bio-formulate. The dehydrated powder obtained by the continuous preheating approach had a viability value 1.37 times higher than the powder obtained during batch preheating method. The cost involved due to electricity consumption is 1.4 times higher in batch preheating method as compared with continuous preheating process, while regarding reagents consumption it is near 3 times higher. It's concluded that the proposed tubular heat exchanger constitutes a profitable and feasible alternative to apply during the bio-formulate preheating step in substitution of the actual batch preheating procedure.
\end{abstract}

Keywords: Tubular heat exchanger, bio-formulate, cell viability, cost.

\section{Resumen}

Actualmente el desarrollo e implementación de procesos térmicos más eficientes y rentables constituye un tópico de alta prioridad en un gran número de industrias y plantas químicas. En el presente trabajo se realiza la evaluación experimental de un intercambiador de calor tubular con el fin de precalentar una suspensión líquida celular (bio-formulado) de la bacteria Tsukamurella paurometabola cepa C-924, en sustitución del actual método de precalentamiento por lotes. Se llevaron a cabo estudios de viabilidad celular, así como también de consumo de energía y reactivos químicos, para ambos métodos de precalentamiento considerados (por lotes y continuo), mientras que los resultados obtenidos se compararon entre sí. El método de precalentamiento por lotes reduce la viabilidad celular del bio-formulado en 75\% durante las primeras 6 horas de precalentamiento, mientras que la aplicación del método de precalentamiento en continuo no reduce la viabilidad del bio-formulado. El polvo deshidratado obtenido durante el precalentamiento en continuo tuvo un valor de viabilidad 1.37 veces superior al polvo obtenido durante el precalentamiento por lotes. El costo por consumo de electricidad es 1.4 veces mayor en el método de precalentamiento por lotes, respecto al proceso en continuo, mientras que el consumo de reactivos químicos, fue 3 veces mayor. Se concluye que el intercambiador de calor tubular propuesto constituye una alternativa rentable y factible de aplicar en la etapa del proceso.

Descriptores: Intercambiador de calor tubular; bio-formulado; viabilidad celular, costo. 


\section{INTRODUCTION}

Heat transfer constitutes an operation widely used in actual industry, which is carried out through the use of specific equipment named heat exchangers. A heat exchanger is used to transfer heat from a hot fluid to a cold one at the maximum rate possible and with the minimum investment required (Kern, 1999). It constitutes equipment quite used in several important industries such as chemical, petrochemical, food and biotechnological, although its field of service comprises practically all the industrial applications. Today there is a current trend in designing compact heat exchangers capable of supply the heat rate required by the process and occupy, in turn, the minimum space possible inside the plant. Considering that, one of the main challenges usually found when designing or assessing heat exchangers is about to obtain a compact equipment by means of which high heat transfer rates are obtained requiring the minimum pumping power, pressure drop and space occupation possible (Cao, 2010). Double tube (tubular) heat exchangers are used fundamentally in those applications without phase change needing less than $18.6 \mathrm{~m}^{2}$ of total effective heat transfer area and little space to carry out them (Kern, 1999; Cao, 2010).

Nowadays, the Center of Genetic Engineering and Biotechnology of Camagüey (CIGB) employs the bacteria Tsukamurella paurometabola strain C-924 as the active agent to obtain the ecologic bionematicide HeberNem ${ }^{\circledR}$. The manufacturing process currently established to obtain this bio-product includes the usual steps employed in a process of this kind, that is, cell propagation; submerged aerobic fermentation; biomass recovery by centrifugation; liquid formulation and bottling, thus obtaining a liquid cell suspension (bio-formulate) containing both Tsukamurella paurometabola bacteria as well as the formulation salts. In recent years several studies at different scales have been accomplished in order to obtain this bio-product in solid state (powder), through the addition of a spray drying procedure once finished the formulation process.

Previous investigations done related with this subject have suggested preheating the bio-formulate to a temperature of $37^{\circ} \mathrm{C}$, before being fed to the spray dyer (Hernández, 2009). The objective of this pre-heating approach consists, fundamentally, in improving the heat and mass transfer operations occurring inside the spray chamber (that is, to increase the efficiency of the overall drying process) as well as the generation of thermal stress response proteins inside the cells (i.e. enhance cell protection) (Paneque, 2010). Also, this is the temperature value to apply for optimum growth of this bacte- rium (Hernández, 2009). However, the preheating method currently employed (batch) is not adequate from the thermal point of view due to, basically, the long preheating times obtained and inadequate handling of the bio-formulate being preheated, resulting in low cell viability values for the preheated bio-formulate prior to being fed to the spray dryer. Taking into account the above-mentioned, it has been considered to use a tubular heat exchanger (Figure 1) to continuously preheat the bio-formulate, with the aim to substitute the current batch preheating method.

Several authors have evaluated the performance of tubular heat exchangers for certain industrial applications. In that sense, (Zhang et al., 2012) studied experimentally the heat transfer processes occurring in a tubular heat exchanger equipped with helical fins and vortex generators (accessories). The results obtained were compared with those obtained in a tubular heat exchanger without accessories (smooth). The working fluids employed were air and water, while the results obtained showed that the heat transferred in the tubular heat exchanger equipped with accessories was $87-115 \%$ higher than the heat transferred in the smooth tubular heat exchanger. Maghlany (2012) studied the fluid flow and heat transfer phenomena taking place in a tubular heat exchanger equipped with an inner rotating tube. The experiments were carried out at a rotating speed between $0-1000 \mathrm{rpm}$, finding out that an increment of the tube rotating speed increases both the Reynolds number and the Number of Transfer Units (NTU) of the system. Finally, Rao and Kumar (2014) evaluated the thermal performance of a tubular heat exchanger using three different types of accessories (fins): rectangular, triangular and parabolic, and varying the feed flowrate of both the hot and cold fluids (water in both cases). Best results regarding heat transfer efficiency were obtained when using triangular fins, while parabolic fins exhibit the minimum values of pressure drop.

The main objective of this work consists then to evaluate experimentally the performance of a tubular heat exchanger to preheat continuously a cell suspension (bio-formulate) of Tsukamurella paurometabola bacteria before being fed to the spray dryer, in order to substitute the current inefficient batch preheating method, thus elevating the processing quality and efficiency parameters of this process step. 


\section{MATeRials AND METHODS}

\section{DESCRIPTION OF THE BATCH PREHEATING METHOD}

The batch preheating method starts when Tsukamurella paurometabola biomass, previously obtained by centrifugation, is mixed with sucrose and other salts in a 250 $\mathrm{L}$ blending tank to obtain the bio-formulate. Then, this liquid formulation is slowly agitated for 12 hours approximately in the same vessel at a temperature between $4^{\circ} \mathrm{C}-10^{\circ} \mathrm{C}$. This operation is carried out in order to fortify the bacteria's organelles and cell wall, thus reducing probable physical damages during the drying process (Cruz, 2006; Hernández, 2009). Bio-formulate preheating process is carried out in a $20 \mathrm{~L}$ jacketed tank employing hot water at $54^{\circ} \mathrm{C}$ as the heating agent coming from a water bath. In this tank, the bio-formulate is preheated to achieve a temperature of $37^{\circ} \mathrm{C}$, approximately. Once reached this temperature, the preheated bio-formulate is pumped to the spray dryer at a flowrate of $20 \mathrm{~L} / \mathrm{h}$ by means of a screw pump (MonoPUMP Ltd.). The preheating process is carried out all the time that the drying process lasts (Figure 2).

Two experimental studies will be accomplished in order to evaluate the influence of preheating time in the cell viability of the preheated bio-formulate prior to being fed to the spray dryer, which are:

1) Taking samples each 6 hours, for a total time of 40 hours, of the bio-formulate being preheated in the $20 \mathrm{~L}$ jacketed tank, prior to being fed to the dryer.

2) Taking samples each 1 hour, for a total time of 6 hours, of the bio-formulate being preheated in the $20 \mathrm{~L}$ jacketed tank, prior to being fed to the dryer.
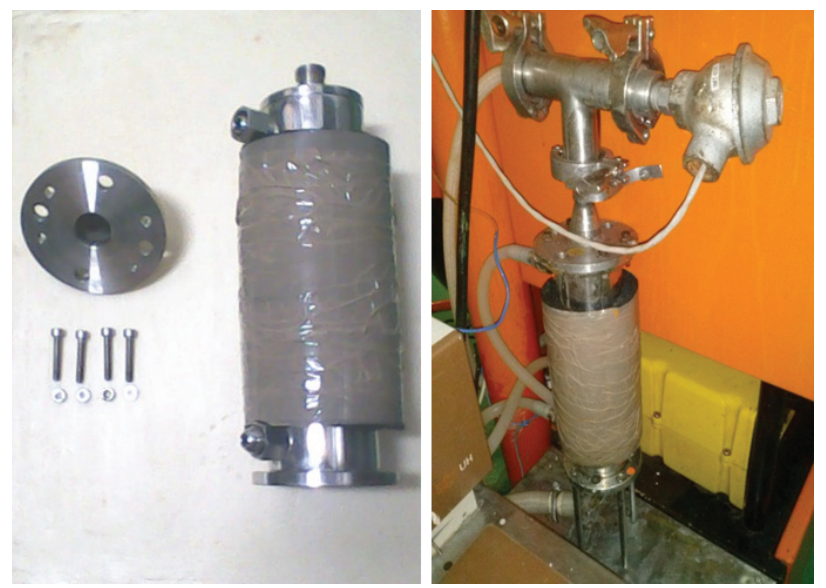

Figure 1. Proposed heat exchanger

\section{PROPOSAL OF THE CONTINUOUS PREHEATING PROCESS}

The bio-formulate is pumped to the feeding funnel by means of a peristaltic pump (Watson-Marlow), at which it's collected and then pumped to the tubular heat exchanger at a rate of $20 \mathrm{~L} / \mathrm{h}$, using an screw pump (MonoPUMP Ltd.). Inside the tubular heat exchanger, the temperature of the bio-formulate is increased from about $10^{\circ} \mathrm{C}$ to $37^{\circ} \mathrm{C}$. Once preheated, the bio-formulate is finally sent to the spray dryer, inside of which the cells are atomized, dehydrated, separated from the airdust mixture, and finally collected (in the form of dehydrated granulated powder) in an air-locked metallic vessel (Figure 3). The heat exchanger uses hot water as the heating agent coming from a water bath, which should be fed at a temperature of $48^{\circ} \mathrm{C}$ according to recommendations established by Ramos (2011).

The main parameters considered for evaluating the effectiveness of the continuous preheating process using the proposed tubular heat exchanger are:

- Cell viability of the bio-formulate both at the heat exchanger's inlet $\left(\mathrm{Xv}_{1}\right)$ and outlet $\left(\mathrm{Xv}_{2}\right)$, as well as in the dehydrated powder $(X p)$ obtained at the outlet of the spray dryer.

\section{CELL VIABILITY DETERMINATION}

To determine the amount of viable cells (viability) in the bio-formulate, the Plating Drop Method was used depending on the sample's phase:

- Liquid (Bio-formulate): 1 milliliter sample of the liquid bio-formulate was diluted 10 -fold using disti-



Figure 2. Diagram of the batch preheating method 
lled water, until dissolving 108 times its initial volume. Later on, the resulting dilution was inoculated into several plates containing agar medium $(40 \mu \mathrm{L}$ per plate distributed in four $10-\mu \mathrm{L}$ incubation rows) using the same pipette. The plates were incubated at $37^{\circ} \mathrm{C}$ for 48 hours approximately, until colonies were visible. Once finished the incubation period, the colony counting procedure was accomplished.

- Solid (Dehydrated powder): Same as the method previously described, but with the difference that the 10 -fold dilution is done using 1 gram of powder sample.

The cell viability data obtained for the bio-formulate, both at the inlet and outlet of the heat exchanger, as well as in the dehydrated powder recovered at spray dryer's outlet, were processed using the statistical software Statgraphics Centurion XVI, in order to determine several statistical parameters such as mean, variance, typical deviation, curtosis, among others. A statistical comparison was also carried out between the cell viability data obtained for the dehydrated powder for both preheating processes evaluated (batch and continuous), with the aim to determine the influence of the preheating technique in the cell viability of the powder obtained during spray drying prior to being put in bags.

\section{ELECTRICITY AND REAGENTS CONSUMPTION}

Electricity: During preheating process, the following power-consuming equipment is used (Table 1 ).

\section{Continuous Preheating Method}

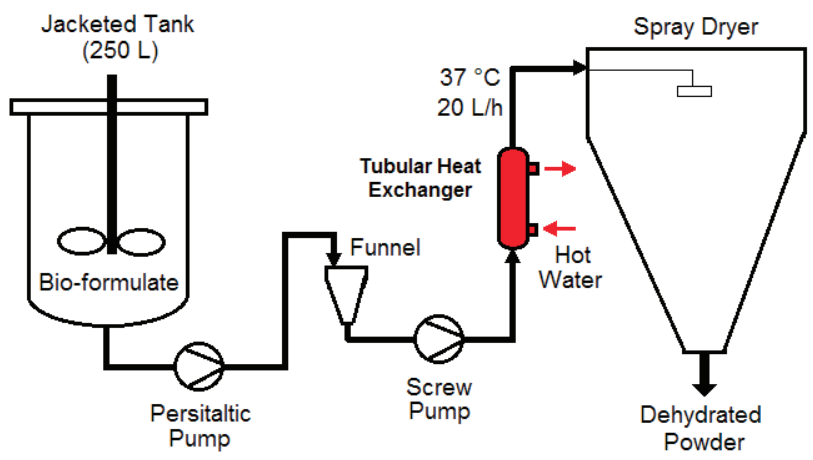

Figure 3. Diagram of the proposed continuous preheating method
The cost related with electricity consumption for single equipment is determined using the following expression

$C_{\text {power (i) }}=t_{\text {oper (i) }} \cdot P_{i} \cdot C_{\text {elect }}$

where

$\mathrm{t}_{\mathrm{oper}(\mathrm{i})}=$ Operating time of the equipment $i(\mathrm{~h})$

$\mathrm{P}_{\mathrm{i}} \quad=$ Nominal power of the equipment $i(\mathrm{~kW})$

$\mathrm{C}_{\text {elect }}=$ Electricity cost $=1.20 \$ / \mathrm{kWh}$

$\mathrm{C}_{\text {power(i) }}=$ Cost associated with the electricity consumption by the equipment $i$ (\$)

Finally, the total cost involved due to electricity consumption by all the equipment used during preheating process will be

$C_{\text {power }(T)}=\sum_{1}^{n} C_{\text {power }(i)}$

where

$n \quad=$ Amount of equipment used during preheating process.

Chemicals: Table 2 shows the amount consumed and the unit cost of each reagent used in both preheating methods.

The cost related with the consumption of the reagent $i$ during preheating process will be determined according to the following expression

$C_{\text {reag (i) }}=Q_{\text {reag }(i)} \cdot P_{\text {reag }(i)}$

Table 1. Characteristics of the power-consuming equipment employed during the preheating process, both for the batch and continuous preheating processes

\begin{tabular}{lcc}
\hline \multicolumn{3}{c}{ Batch } \\
\hline \multicolumn{1}{c}{ Equipment } & $\begin{array}{c}\text { Time } \\
(\mathrm{h})\end{array}$ & Power consumption $(\mathrm{kW})$ \\
\hline Peristaltic pump 1 & 8 & 0.85 \\
Peristaltic pump 2 & 7 & 0.85 \\
Water bath & 7 & 1.20 \\
Jacketed tank (20 L) & 7 & 0.85 \\
Jacketed tank (250 L) & 8 & 2.20 \\
Screw pump & 8 & 2.20 \\
\hline \multicolumn{4}{c}{ Continuous } \\
Equipment & Time & \\
\hline Peristaltic pump & $(\mathrm{h})$ & Power consumption $(\mathrm{kW})$ \\
Water bath & 6 & 0.85 \\
Jacketed tank (250 L) & 6 & 1.20 \\
Screw pump & 7 & 2.20 \\
\end{tabular}


where

$\mathrm{Q}_{\text {reag(i) }} \quad=$ Amount of the reagent $i$ consumed $[\mathrm{kg}$ or $\mathrm{L}]$

$\mathrm{P}_{\text {reag(i) }} \quad=$ Unit cost of the reagent $i(\$ / \mathrm{kg}$ or $\$ / \mathrm{L})$

$\mathrm{C}_{\text {reag(i) }}=$ Cost associated with consumption of the reagent $i(\$)$

The total cost involved due to reagent consumption will be

$C_{\text {reag (T) }}=\sum_{l}^{n} C_{\text {reag }(i)}$

where

$n \quad=$ Amount of reagent consumed during preheating process.

\section{GeOMEtRiC Dimensions of THE PROPOSED tUbULAR heAt EXCHANGER}

The tubular heat exchanger proposed presents the following geometrical dimensions (Table 3).

\section{ResULTS AND DISCUSSION}

RESULTS OBTAINED FOR THE TWO VIABILITY STUDIES ACCOMPLISHED FOR THE BATCH PREHEATING PROCESS

Two viability studies were carried out in order to determine the influence of batch preheating time in the cell viability of the bio-formulate. The results obtained for the first experimental viability study accomplished, that is, batch preheating of the bio-formulate for 40 hours, are showed in Figure 4, while Figure 5 shows the results obtained for the second experimental cell viability study realized, that is, batch preheating of the bioformulate for 6 hours.

where

Table 2. Summary of the different reagents consumed for both preheating methods

\begin{tabular}{lcc}
\hline \multicolumn{1}{c}{ Chemical } & $\begin{array}{c}\text { Amount } \\
\text { consumed }\end{array}$ & $\begin{array}{c}\text { Unit } \\
\text { cost }\end{array}$ \\
\hline \multicolumn{3}{c}{ Batch preheating } \\
\hline Sodium hydroxide (pellets) & $80 \mathrm{~g}$ & $\$ 0,054 / \mathrm{kg}$ \\
o-Phosphoric acid & $30 \mathrm{~mL}$ & $\$ 0,2352 / \mathrm{L}$ \\
Water & $60 \mathrm{~L}$ & $\$ 0,05 / \mathrm{L}$ \\
\hline \multicolumn{4}{c}{ Continuous preheating } \\
\hline $\begin{array}{l}\text { Sodium hydroxide (pellets) } \\
\text { o-Phosphoric acid }\end{array}$ & $40 \mathrm{~g}$ & $\$ 0,054 / \mathrm{kg}$ \\
Water & $15 \mathrm{~mL}$ & $\$ 0,2352 / \mathrm{L}$ \\
\hline
\end{tabular}

$X_{V}=$ Viable cells count at time $\mathrm{t}$

$X_{\mathrm{O}}=$ Viable cells count at initial time 0

Analyzing the results obtained in Figure 4 it can be observed that in the first 6 hours of preheating a $75 \%$ reduction of bio-formulate cell viability occurs. This is because a progressive nutrient and oxygen consumption takes place throughout almost all the time the batch preheating process lasts, which causes that the bacterial cells start an autolysis process and enter into the cellular death phase. This also promotes the generation of insufficient amounts of thermal shock response proteins by the cells, which impedes an adequate response to the high temperatures usually applied during the drying process. This phenomenon can also be observed in Figure 5, where during the first 6 hours of batch preheating method the cell viability decreases about $75 \%$ too. Taking into account both results obtained, it can be concluded that the batch preheating method is not adequate to be used prior to the spray drying process since the cell viability of the preheated bio-formulate is reduced way more than $20 \%$, which is the limit value established by the internal quality standards of the CIGB to classify this process stream as adequate prior to being fed to the spray dryer.

\section{VIABILITY TEST RESULTS OBTAINED FOR CONTINUOUS PREHEA- TING PROCESS USING THE TUBULAR HEAT EXCHANGER}

Table 4 shows the results obtained for the cell viability tests carried out for the bio-formulate both at the inlet and outlet of the tubular heat exchanger, while an statistical summary of the viability results obtained at those points are observed in Table 5 .

Analyzing the results showed in both tables it can be concluded that the continuous preheating process don't reduces the cell viability of the bio-formulate, since it's not observed a decrease in the value of this parameter

Table 3. Geometric dimensions of the tubular heat exchanger proposed

\begin{tabular}{|c|c|c|}
\hline Variable & Value & Units \\
\hline \multicolumn{3}{|c|}{ Annulus } \\
\hline Inner diameter & 0.074 & $\mathrm{~m}$ \\
\hline Outer diameter & 0.076 & $\mathrm{~m}$ \\
\hline \multicolumn{3}{|c|}{ Inner tube } \\
\hline Inner diameter & 0.0555 & $\mathrm{~m}$ \\
\hline Outer diameter & 0.0575 & $\mathrm{~m}$ \\
\hline \multicolumn{3}{|c|}{ Other } \\
\hline Length & 0.35 & $\mathrm{~m}$ \\
\hline Material & Sta & \\
\hline
\end{tabular}




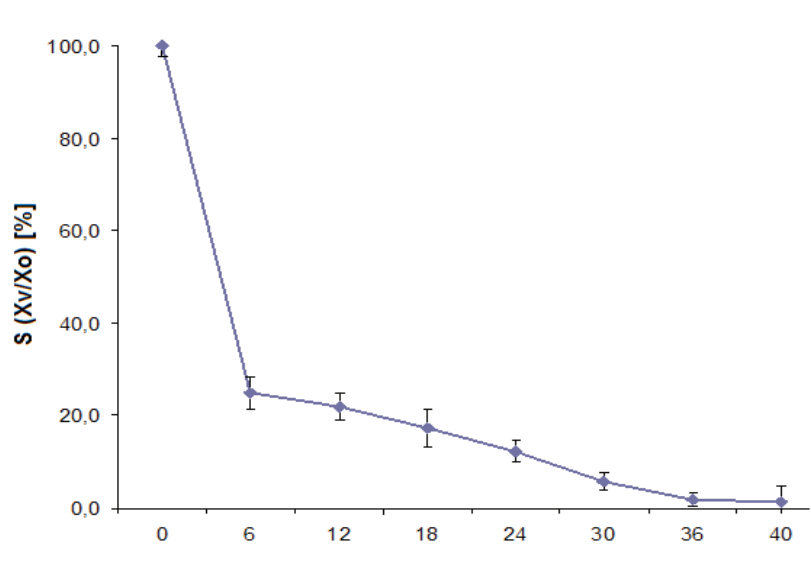

Figure 4. First viability study carried out for batch preheating method

at the outlet of the tubular heat exchanger. This is due, fundamentally, to the low retention times experimented by the bio-formulate when flowing inside the heat exchanger (about 5-7 seconds), which reduces the exposition time of the cells to the preheating temperature, thus reducing the probable occurrence of cell stress processes and then autolysis.

According to that, the increased velocity of the continuous preheating process has positive influence on the cell viability results obtained for the bio-formulate.

\section{COMPARISON OF THE CELL VIABILITY RESULTS OBTAINED FOR THE DEHYDRATED POWDER IN BOTH PREHEATING METHODS EVALUATED}

Table 6 shows a comparison between the cell viability results obtained for the dehydrated powder for the two preheating methods considered, while Table 7 shows a statistical summary about the cell viability results obtained for the dehydrated powder also for both preheating methods assessed.

Taking into account the values showed in Table 6, the average cell viability obtained for the dehydrated powder is about 1.37 times higher when applying the continuous preheating method, compared with the value obtained of this parameter when using the batch preheating method. This is because there is no significant reduction of the bio-formulate cell viability during continuous preheating method by using the proposed tubular heat exchanger. That is, the cell viability of the bio-formulate is kept almost constant during continuous preheating method, which doesn't occur in the batch preheating method where the cell viability of the bio-formulate is reduced by near $75 \%$ in the first 6 hours of preheating. This has a strong influence on the low values of cell viability further obtained for the dehydra-

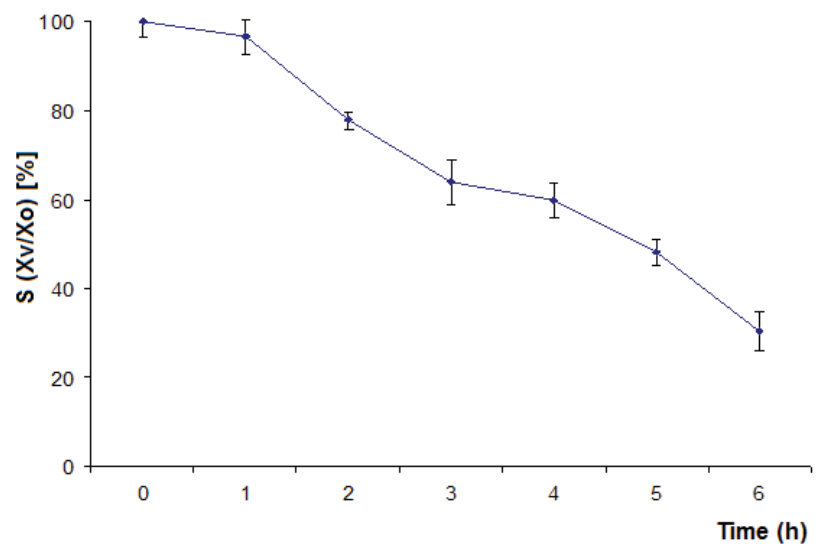

Figure 5. Second viability study carried out for batch preheating method

ted powder at the outlet of the spray dryer. The later corroborate that the high velocity at which the continuous preheating method takes place affects positively the results of cell viability obtained during later process operations, in this case the spray drying step.

\section{COMPARISON OF THE COSTS OBTAINED DUE TO ELECTRICI- TY AND REAGENTS CONSUMPTION FOR BOTH PREHEATING METHODS EVALUATED}

Tables 8 and 9 describe the cost results obtained due to electricity and reagents consumption, respectively, for both preheating methods evaluated.

According to the results showed in Table 8, it can be observed that the cost results obtained due to electricity consumption for the batch preheating method are about 1.4 times higher in comparison with the results obtained for the continuous process. This is because this method uses a higher amount of equipment functioning longer times. Finally, the costs due to reagent consumption are approximately 3 times higher for the batch preheating method as compared with the continuous process using the tubular heat exchanger. This is owing to, fundamentally, the use of a higher quantity of equipment, hoses and accessories in the batch preheating method, which then need to be washed and sanitized once finished the preheating process in order to be used in the next batch. In this sense, greater amounts of equipment used during preheating method will lead to greater amounts of reagents consumed to sanitize and clean them. 
Table 4. Cell viability results obtained for the bio-formulate both at the inlet and outlet of the tubular heat exchanger

\begin{tabular}{ccccc}
\hline \multirow{2}{*}{ Run } & \multicolumn{2}{c}{ Cell viability $(\mathrm{CFU} / \mathrm{mL})$} & \multicolumn{2}{c}{ Log viability } \\
\cline { 2 - 5 } & Inlet & Outlet & Inlet & Outlet \\
\hline 1 & $5,0 \cdot 10^{11}$ & $5,0 \cdot 10^{11}$ & 11,6990 & 11,7076 \\
2 & $4,9 \cdot 10^{11}$ & $4,9 \cdot 10^{11}$ & 11,6902 & 11,6902 \\
3 & $4,8 \cdot 10^{11}$ & $4,8 \cdot 10^{11}$ & 11,6812 & 11,6721 \\
4 & $5,0 \cdot 10^{11}$ & $4,9 \cdot 10^{11}$ & 11,6990 & 11,6902 \\
5 & $4,7 \cdot 10^{11}$ & $4,7 \cdot 10^{11}$ & 11,6721 & 11,6721 \\
6 & $4,9 \cdot 10^{11}$ & $5,0 \cdot 10^{11}$ & 11,6902 & 11,6990 \\
7 & $4,8 \cdot 10^{11}$ & $4,8 \cdot 10^{11}$ & 11,6812 & 11,6990 \\
8 & $5,0 \cdot 10^{11}$ & $5,0 \cdot 10^{11}$ & 11,6990 & 11,6812 \\
Average & $4,89 \cdot 10^{11}$ & $4,89 \cdot 10^{11}$ & 11,689 & 11,689 \\
\hline
\end{tabular}

Table 5. Statistical resume of the cell viability results obtained for the bio-formulate both at the tubular heat exchanger inlet and outlet

\begin{tabular}{lcc}
\hline \multicolumn{1}{c}{ Variable } & Inlet & Outlet \\
\hline Frequency & 8 & 8 \\
Mean & 11,689 & 11,689 \\
Variance & 0,000101453 & 0,000168694 \\
Typical Deviation & 0,0100724 & 0,0129882 \\
Minimum & 11,6721 & 11,6721 \\
Maximum & 11,699 & 11,7076 \\
Range & 0,0269 & 0,0355 \\
Asymmetry & $-0,591$ & $-0,142962$ \\
Curtosis & $-0,543436$ & $-0,699992$ \\
\hline
\end{tabular}

Table 6. Cell viability results obtained for the dehydrated powder for both preheating methods

\begin{tabular}{ccccc}
\hline Run & \multicolumn{2}{c}{ Cell viability $(\mathrm{CFU} / \mathrm{mL})$} & \multicolumn{2}{c}{ Log viability } \\
\cline { 2 - 5 } & Batch & Continuous & Batch & Continuous \\
\hline 1 & $3.3 \cdot 10^{12}$ & $4.7 \cdot 10^{12}$ & 12.5185 & 12.6721 \\
2 & $3.5 \cdot 10^{12}$ & $4.8 \cdot 10^{12}$ & 12.5441 & 12.6812 \\
3 & $3.8 \cdot 10^{12}$ & $4.9 \cdot 10^{12}$ & 12.5798 & 12.6902 \\
4 & $3.6 \cdot 10^{12}$ & $4.9 \cdot 10^{12}$ & 12.5563 & 12.6902 \\
5 & $3.4 \cdot 10^{12}$ & $5.0 \cdot 10^{12}$ & 12.5315 & 12.6990 \\
6 & $3.6 \cdot 10^{12}$ & $4.9 \cdot 10^{12}$ & 12.5563 & 12.6902 \\
7 & $3.5 \cdot 10^{12}$ & $4.8 \cdot 10^{12}$ & 12.5441 & 12.6812 \\
8 & $3.8 \cdot 10^{12}$ & $4.9 \cdot 10^{12}$ & 12.5798 & 12.6902 \\
Average & $3.56 \cdot 10^{12}$ & $4.86 \cdot 10^{12}$ & 12.5513 & 12.6868 \\
\hline
\end{tabular}

Table 7. Statistical resume about the cell viability results obtained for the dehydrated powder for both preheating methods evaluated

\begin{tabular}{lcc}
\hline \multicolumn{1}{c}{ Variable } & Inlet & Outlet \\
\hline Frequency & 8 & 8 \\
Mean & 12.5513 & 12.6868 \\
Variance & 0.000463723 & 0.0000676984 \\
Typical Deviation & 0.0215342 & 0.0082279 \\
Minimum & 12.5185 & 12.6721 \\
Maximum & 12.5798 & 12.699 \\
Range & 0.0613 & 0.0269 \\
Asymmetry & 0.0606095 & -0.606867 \\
Curtosis & -0.40136 & 0.249327 \\
\hline
\end{tabular}




\section{Conclusions}

During the batch preheating method, the cell viability of the bio-formulate is reduced about $75 \%$ in the first 6 hours.

The application of the continuous preheating method doesn't reduce the cell viability of the preheated bio-formulate prior to being fed to the spray dryer.

The dehydrated powder obtained by applying continuous preheating method had an average cell viability value about 1.37 times higher in comparison with the dehydrated powder obtained by means of batch preheating method.
The costs due to electricity and reagent consumption for the batch preheating method are about 1.4 and 3 times higher, respectively, as compared with the costs obtained for the continuous preheating process.

It's feasible to implement, from the techno-economic point of view, the tubular heat exchanger during the preheating step, in substitution of the current batch preheating approach.

\section{RefERenCES}

Cao E. Heat transfer in process engineering, New York, McGrawHill, 2010, pp. 79-108.

Table 8. Costs results obtained due to electricity consumption for both preheating methods

\begin{tabular}{|c|c|c|c|}
\hline \multicolumn{4}{|c|}{ Batch } \\
\hline Equipment & $\begin{array}{l}\text { Time } \\
\text { (h) }\end{array}$ & $\begin{array}{l}\text { Nominal power } \\
\qquad(\mathrm{kW})\end{array}$ & $\begin{array}{c}\text { Cost } \\
\text { (\$/batch) }\end{array}$ \\
\hline Peristaltic pump 1 & 8 & 0.85 & 8.16 \\
\hline Peristaltic pump 2 & 7 & 0.85 & 7.14 \\
\hline Water bath & 7 & 1.20 & 10.08 \\
\hline Jacketed tank (20 L) & 7 & 0.85 & 7.14 \\
\hline Jacketed tank (250 L) & 8 & 2.20 & 21.12 \\
\hline Screw pump & 8 & 2.20 & 21.12 \\
\hline Total & & & 74.76 \\
\hline \multicolumn{4}{|c|}{ Continuous } \\
\hline Equipment & $\begin{array}{l}\text { Time } \\
\text { (h) }\end{array}$ & $\begin{array}{l}\text { Nominal power } \\
(\mathrm{kW})\end{array}$ & $\begin{array}{c}\text { Cost } \\
\text { (\$/batch) }\end{array}$ \\
\hline Peristaltic pump & 6 & 0.85 & 6.12 \\
\hline Water bath & 6 & 1.20 & 8.64 \\
\hline Jacketed tank $(250 \mathrm{~L})$ & 7 & 2.20 & 18.48 \\
\hline Screw pump & 8 & 2.20 & 21.12 \\
\hline Total & & & 54.36 \\
\hline
\end{tabular}

Table 9. Costs results obtained due to reagents consumption for both preheating methods

\begin{tabular}{lccc}
\hline \multicolumn{3}{c}{ Batch } & \\
\hline Equipment & Reagent & Unit & Cost \\
consumption & cost & $(\$ /$ batch $)$ \\
Sodium hydroxide & $80 \mathrm{~g}$ & $\$ 0.054 / \mathrm{kg}$ & 0.004 \\
o-Phosphoric acid & $30 \mathrm{~mL}$ & $\$ 0.2352 / \mathrm{L}$ & 0.007 \\
Water & $60 \mathrm{~L}$ & $\$ 0.05 / \mathrm{L}$ & 3.000 \\
Total & & & 3.011 \\
\hline & Continuous & & \\
\hline & Reagent & Unit & Cost \\
Equipment & consumption & cost & $(\$ /$ batch $)$ \\
Sodium hydroxide & $40 \mathrm{~g}$ & $\$ 0.054 / \mathrm{kg}$ & 0.002 \\
o-Phosphoric acid & $15 \mathrm{~mL}$ & $\$ 0.2352 / \mathrm{L}$ & 0.004 \\
Water & $20 \mathrm{~L}$ & $\$ 0.05 / \mathrm{L}$ & 1.000 \\
Total & & & 1.006 \\
\hline
\end{tabular}


Cruz F. Estudio de la expresión de las proteínas de choque térmico en M. xanthus, México, Centro de Investigación y Estudios Avanzados, 2006, 63 p.

Hernández A. Evaluación y predicción del estado de anhidrobiosis en Tsukamurella paurometabola C-924, (tesis doctorado, ciencias técnicas), Cuba, Universidad de la Habana, 2009, 236 pp.

Kern D.Q. Procesos de transferencia de calor, México D.F., Compañía Editorial Continental S.A. de C.V., 1999, pp. 131-145.

Maghlany W.E., Eid E., Teamah M., Shahrour L. Experimental study for double pipe heat exchanger with rotating inner pipe. International Journal of Advanced Scientific and Technical Research, volume 4 (issue 2), 2012: 507-524.

Paneque Y. Caracterización fenomenológica del proceso de secado por atomización del HeberNem-S en el Centro de Ingeniería y Biotecnología de Camagüey, (trabajo de grado, ingeniería química), Cuba, Universidad de Camagüey, 2010, 189 pp.

Rao P.S. and Kumar K.K. Numerical and experimental investigation of heat transfer augmentation in double pipe heat exchanger with helical and twisted tape inserts. International Journal of Emerging Technology and Advanced Engineering, volume 4 (issue 9), 2014: 180-192.

Ramos L. Influencia del proceso de secado por atomización en la viabilidad celular de la Tsukamurella paurometabola C-924 del bionematicida HeberNem-S, (trabajo de grado, ingeniería química), Cuba, Universidad de Camagüey, 2011, 136 pp.

Zhang L., Guo H., Wu J., Du W. Compound heat transfer enhancement for shell side of double-pipe heat exchanger by helical fins and vortex generators, Heat and Mass Transfer, volume 48, 2012: 1113-1124. 


\section{Suggested citation}

\section{Chicago style citation}

Pérez-Sánchez, Amaury, Yunier Paneque-Díaz, Lisandro Ramos-López, Jesús Zamora-Sánchez, Lourdes Crespo-Zafra. Evaluation of a tubular heat exchanger for preheating a cell suspension of Tsukamurella paurometabola. Ingeniería Investigación y Tecnología, XVIII, 03 (2017): 331-340.

\section{ISO 690 citation style}

Pérez-Sánchez A., Paneque-Díaz Y., Ramos-López L., Zamora-Sánchez J., Crespo-Zafra L. Evaluation of a tubular heat exchanger for preheating a cell suspension of Tsukamurella paurometabola. Ingeniería Investigación y Tecnología, volume XVIII (issue 3), July-September 2017: 331-340.

\section{About the AUthors}

Amaury Pérez-Sánchez. Since its graduation as Chemical Engineer in 2009 year he worked during 5 years as production specialist in the Centre of Genetic Engineering and Biotechnology of Camagüey. Since 2014 he's working in the University of Camagüey as instructor professor, and its specialization field comprises fundamentally mass and heat transfer operations in chemical and biotechnological processes, as well as chemical equipment design.

Yunier Paneque-Díaz. Since its graduation as Chemical Engineer in 2010 year, he has been working at the Centre of Genetic Engineering and Biotechnology of Camagüey as production specialist, mostly in the areas of drying, fermentation and vaccines formulation. Its professional specialization field comprises fundamentally mass transfer operations; bio-products spray drying and submerged fermentation.

Lisandro Ramos-López. Since its graduation as Chemical Engineer in 2011 year, he has been working at the University of Camagüey in the Department of Aliments as Instructor Professor. It's specialized mostly in innocuous processing of foodstuffs, industrial microbiology and media sterilization.

Jesús Zamora-Sánchez. Graduated in Radiochemistry, he has worked over 20 years at the Centre of Genetic Engineering and Biotechnology (CIGB) of Camagüey in several areas, mostly in production and management. Specialist in vaccines fermentation, purification and formulation operations. He's now the director of the CIGB.

Lourdes Crespo-Zafra. Since its graduation as a Chemical Engineer, she has been working at the University of Camagüey fundamentally in the Chemical Engineering Department. Its professional specialization field comprises energetic evaluation of chemical, petrochemical and biotechnological processes, as well as flow of fluids and mass transfer operations. 